\title{
Common ground as battleground: the culture wars framing bioethics continue ${ }^{\#}$
}

\section{Pontos comuns como resultado do campo de batalha: guerras culturais e 0 enquadramento da bioética continuam}

H. Tristam Engelhardt Jr.*

\section{CHAPTER SEVEN}

\section{Bioethics, the Culture Wars, and Western Christianity: Assessing the Current Terrain}

There is no cultural peace. We are in a culture war defined by disagreements. Salient among the disagreements are bioethical battles about abortion, human embryo stem-cell research, artificial insemination of unmarried women, reproduction in marriage with the use of donor gametes, healthcare allocation, physicianassisted suicide, and euthanasia, to name only a few issues. In great part, these disputes exist because of the collision of traditional Christian morality and bioethics with the morality and bioethics of the dominant secular culture. Most salient is traditional Christianity's rejection of the demoralization of morality and bioethics, as well as of the aggressive secularization of the public space (Hunter 1991). The cultural geography of these profound disagreements frames the public discourse of bioethics and healthcare policy. The character of this public discourse is crucially tied to the secularization and the deChristianization of the West. Contemporary bioethics itself arose within the collapse of mainline Christian- ity. This chapter shows how the emergence of contemporary secular bioethics is in particular closely associated with ecclesial and theological changes in Roman Catholicism, the largest of the Christian denominations, which changes led to the abandonment of its previous paradigm of medical ethics and the emergence of secular bioethics. Contemporary secular bioethics under the term bioethics as it developed at Georgetown University, a Jesuit university, in the 1970s was intimately tied to conditions within post-Vatican II Roman Catholicism. Contemporary secular bioethics has important roots in the disputes characterizing Roman Catholicism in the late 1960s and early 1970s.

To appreciate the place of Christian bioethics in the contemporary debates, this chapter examines as well the role of Roman Catholic thinkers in attempting to bring peace to the culture wars by denying as well as blunting difference. It is traditional and/or conservative Christians who are prominent belligerents in the culture wars. The contemporary bioethical culture wars also importantly reflect consequences of the postVatican II (1962-1965) changes in Roman Catholicism, which have left it ever less monolithic

DOI: 10.15343/0104-7809.20153904514530

\# A seção "Bioética no Mundo da Saúde", foi criada para comportar trabalhos de grande relevância na área da Bioética e da Saúde. Nesta edição, dando continuidade à publicação da obra "After God: Morality and Bioethics in a Secular Age", do importante bioeticista Prof. Tristram Engelhardt, Jr, que gentilmente nos cedeu os direitos, será apresentado o capítulo sete. Tal trabalho, foi primeiramente apresentado na seção "artigos em séries", da revista Bioethikos em 2014;8(1):80-88. This chapter is drawn from the following ancestral presentations: "Bioethics after Foundations: Feeling the Full Force of Secularization," conference on Secularization and Bioethics, sponsored by the Centro Evangelico di Cultura "Arturo Pascal" and Consulta di Bioetica Onlus, Turin, Italy, 31 January 2012, and "Religion, Politics, and the State in Modern Secularized Societies," presented to the Comune di Napoli on 6 February 2012. An ancestral version of this chapter appears as Engelhardt 2013.

* Graduado em Medicina e Filosofia. Doutor em Filosofia pela faculdade do Texas-TX, USA. Doutor em Medicina pela Faculdade de Tulane, New Orleans-LA, USA. Professor da Rice University, Houstoun-TX, USA. Autor das obras Fundamentos da Bioética e Fundamentos da Bioética Cristã Ortodoxa, pelas Edições Loyola, e de Bioética Global, pelas Edições Paulinas. E-mail: htengelhardt@juno.com

1. I must admit to having since my youth been disappointed by the claims of moral philosophy regarding sound rational argument. When I was still a Roman Catholic, I had tried to my utmost to use philosophy to secure its natural law, natural theological, and other rationalist claims. I was shocked by my failure. I found that the moral-philosophical and -theological arguments of Roman Catholicism required the concession of crucial and controverted initial premises and rules of inference. Then I discovered that the same difficulty lies at the basis of any secular moral-philosophical viewpoint, morality, or bioethics. This chapter is a special gloss on this difficulty in bioethics. 
in its opposition to the secularity that shapes the bioethics of the dominant culture. The contemporary culture wars are located within this complex territory of conflicting social forces. The cardinal question then arises: given the disarray of Western Christianity, will the bioethical battles in the culture wars continue?

This is not an easy question to answer, especially given the continuing secularization and disorientation of much of Western Christianity. What resources remain to sustain Christianity's counter-cultural character along with its responses to the secular transformation of morality, bioethics, and healthcare policy? Is Western Christianity not itself about to be thoroughly demoralized and in the mode of Paul Tillich (1886-1965) deflated? Can Western Christianity continue to supply recruits for the culture wars? This serious issue regarding the future of the culture wars and the future context for the disputes about bioethics and healthcare policy is a central focus of this chapter. Will the cultural belligerencies concerning bioethics continue? There are grounds for doubting the staying power of Western Christianity. The secularization of Western Christianity, along with false perceptions regarding the character of the disputes resulting especially from a continued commitment to the moral-philosophical project, raise the possibility that even many Christians will not fully appreciate what is at stake: the collision between a secular moral vision with its bioethics, and the moral vision grounded in an experience of God. What is offered in this chapter is a geography of the contemporary Western Christian theological terrain. This is undertaken in order better to appreciate the context within which bioethics arose and in which the culture wars about bioethics now find themselves.

\section{Making Way for a New Paradigm for Medi- cal Ethics}

As the last chapter has shown, secular academic bioethics is an arena of interminable disputes, for which theoretical reflections can at best provide a geography of a contentious intellectual territory, but no way out. Healthcare ethics consultation, for its part, has successfully taken possession of a domain of the practice of law, so that it offers what amounts to legal advice. However, the ethics established at law and in public policy is often strongly in tension with the obligations of Christian healthcare professionals. This complex phenomenon of secular bioethics occasions the culture wars because, if nothing else unites secular bioethics, it is united by an understanding of itself as after Christianity. Chapter Four addresses this point by showing why traditional Christians find themselves in positions where they are unable to compromise with the demands of law and public policy established by secular fundamentalist states where a particular secular ideology plays a role analogous to the role religion plays in a religious fundamentalist state (Engelhardt 2010a and 2010b). But who are those who remain in opposition to the secular state's violation of their consciences? What is the character of their opposition? Answering such questions is core to understanding the culture wars and the place of bioethics in them. This chapter focuses primarily, but not exclusively, on the role played by Roman Catholicism, in that it is the largest and by far the most organized of the Christianities. Moreover, it was the origin of secular bioethics.

The belligerence of the culture wars depends on the vigor of the disputing parties. The party of the secular is generally quite dedicated. Therefore, the character and strength of the battles depend on the strength of the response of those committed to traditional Christian moral and bioethical positions, primarily traditional Christians who reject the demoralization and deflation of bioethics and morality. As a consequence, these conflicts have a different character in different polities, depending chiefly on the strength of the religious groups within their jurisdictions. Often, the response of the locally dominant Christianities will be mild at best. Foreshadowing recent changes in Roman Catholicism, the mainline Protestant Christian churches from the mid-18th and early 19th century abetted secularization and desacralization as they themselves were transformed. A powerful early and continuing 
influence on the secularization of Protestantism was Immanuel Kant's project of reducing religion to its moral significance, so that it did not matter to which religion one belonged, as long as one lived a "moral" life. Doctrinal substance became irrelevant.

We have good reason to say...that "the kingdom of God is come unto us" once the principle of the gradual transition of ecclesiastical faith to the universal religion of reason, and so to a (divine) ethical state on earth, has become general and has also gained somewhere a public foothold, even though the actual establishment of this state is still infinitely removed from us (Kant 1960, p. 113, AK VI 114).

Kant endorsed a moral and social gospel. Faith in such a universal religion of reason was sufficiently widespread among intellectuals at the beginning of the 19th century that some liberal Jews, admittedly for a complex set of reasons, considered entering into some form of congregational union with liberal Protestants of equally sparse confessional commitments (Hess 2002, esp. pp. 176-182).

Before the mid-20th century, the results of secularization were already widespread in central Europe. In Germany in particular by the late 19th century, mainline Protestantism was largely moribund. As Eduard von Hartmann (1842-1906) noted, "Liberal Protestantism has necessarily become an irreligious phenomenon of history, because Protestantism has taken the interest of modern culture to be the criterion" (von Hartmann 1874, p. 87). Mainline Protestantism was effecting its own Selbstzersetzung, its own self-destruction. This secularization was described in various ways and promoted by Friedrich Schleiermacher (1763-1834), Arthur Schopenhauer (1788-1860), Ludwig Feuerbach (1804-1872), and David Strauss (1808-1874). There was a widespread Verweltlichung (secularization) of Protestant Christianity (Overbeck 1919 , p. 245). By the early 20th century in Germany, the transformation had been thoroughgoing. As Émile Durkheim (1858-1917) puts it, "the old gods are growing old or already dead, and others are not yet born" (Durkheim 1947, p. 427). An analogous secularization and deflation of dogma marked Protestantism in many areas of the northern United States, especially in New England. It was in reaction against liberal Protestantism that fundamentalist Christianity developed its identity at the end of the 19th and the beginning of the 20th century.

Finally, a Protestantism emerged that was fully after God, a liberal Protestantism that realized itself in a social gospel and moral commitments without a metaphysics of transcendence. Some of these Protestants were influenced by and were intellectual descendants of Hegel. As Charles Taylor puts it:

Thus while Hegel is not in the main line of descent of liberal Protestantism, he is the point of origin of another important movement towards a de-mythologized, one might say, 'de-theologized' Christianity. Contemporary theologies of 'the death of God' are his spiritual grandchildren. The filiation is either direct, as with Paul Tillich who very much influenced the theologians of this school, or through the young Hegelian Ludwig Feuerbach (Taylor 1975, p. 495).

One must therefore wonder about the meaning of the gloss by Emil Fackenheim on Karl Barth regarding Hegel. "We may rely on Karl Barth's apt formulation that Hegel seeks to do for the modern Protestant world what St. Thomas Aquinas has done for the Catholic Middle Ages" (Fackenheim 1967, p. 10). An Orthodox Christian would take this to be a subtle way of also criticizing Aquinas's effect on Western Christianity. In any event, by the late 20th century, one had with figures such as Paul Tillich (1886-1965) Christian theologians without belief in the God of the Christians. As Richard Rorty remarked, when people asked why [Tillich] didn't stop pretending to be a Christian theologian and instead bill himself as a Heideggerian philosopher. He would say, in effect that it was precisely the job of a Christian theologian these days to find a way of making it possible for Christians to continue using the term 'Christ' even after they had given up supernaturalism (as he hoped they eventually would)" (Rorty 1991, p. 70). A post-Christian Christianity had emerged. 
Contrary to the assertion of Edward S. Shapiro, in the dominant secular culture it is not the case that "If a Christian is secularized and becomes an atheist or an agnostic, he ceases being a Christian" (Shapiro 2014, p. 42), as the counter-examples of G.W.F. Hegel and Paul Tillich ably attest. Christians, like Jews, can become acceptable Christians within the contemporary culture precisely when they are atheists or at least agnostics. The sacred has been placed within the horizon of the finite and the immanent. Thomas Luckmann appreciates this deflation or immanentization of the transcendent (an old theme articulated by Hegel in 1802).

The span of transcendence is shrinking. Modern religious themes such as "self-realization," personal autonomy, and self-expression have become dominant. More recently, they have fused either with the newly emerging mix of pseudo-science and magic or with certain rearticulations of the intermediate and great transcendences in the ecological components of the "New Age." The shrinking of transcendence thus does not mean a loss of the "sacred." The dominant themes in the modern sacred cosmos bestow something like a sacred status upon the individual himself by articulating his autonomy. As the transcendent social order and the great transcendences cease to be generally significant, matters that are important to the privatized, partly egoistic and hedonistic, partly ecological, symbolically altruistic individual become sacralized (Luckmann 1990, p. 138).

The only question is whether Jews and Christians can resist these powerful forces in the dominant secular culture?

A fate similar to mainline Protestantism and Reform Judaism was initially resisted by Roman Catholicism, which responded to threats of secularization through Pope Pius IX's (1792-1878, elected 1846) Syllabus of Errors (8 December 1864) and other condemnations of modernism, the complex movement that devalued supernatural elements and sought accommodation to the secular culture. There was as well the condemnation by Pope Leo XIII (1810-1903, elected 1878) of Americanism, which was considered a heresy for supporting inter alia the separation of church and state. Americanism was addressed, for example, in a letter by Pope Leo XIII to Cardinal Gibbons of Baltimore of 22 January 1899 (Denziger 1965, pp. 656-658, novus numerus textum 3340-3346; vetus numerus 1967-1976). Rome was able to bring order by acting from the top down. This included having all seminarians sign an oath against modernism (1 September 1910). Save with regard to the Roman Catholic intellectual class, these measures were largely successful, such that generally parishes were for the most part flourishing, pious, and engaged in charitable outreach. Although these measures were repressive, they fit into an ecclesial culture that was itself generally repressive and had forbidden, among other things, vernacular translations of the Mass (placing them on the Index of Forbidden Books) until the late 19th century. Despite all of these difficulties, there was a high rate of adult conversions. Tendentious histories depict the pre-Vatican II church as ineffective and shallow, notwithstanding the fact that pre-Vatican II Roman Catholicism was marked by high devotion reflected in real "social justice" achieved through hospitals and parochial schools manned by nuns and brothers. There is objective evidence of success before and then collapse after Vatican II (1962-1965). Pre-Vatican II Catholicism was generally functional, and the Catholicism of Vatican II, with that of Popes John XXIII (1881-1963, elected 1958), Paul VI (18971978, elected 1963), and John Paul II (19202005, elected 1978) was generally dysfunctional, secularized, and indeed desacralized.

It must be noted that two features of preVatican II Roman Catholicism made it ripe for a revolution that generated liturgical as well as doctrinal transformation and confusion, if not chaos (Hull 2010). The first was a liturgical movement that had been developing throughout the early 20th century bent on radically recasting the traditional Tridentine Mass. As an example, one might consider the work of Fr. Gerald Ellard, S.J., and his The Mass of the Future (Ellard 1948). An overview of the roots and character of the sweeping changes is offered by one of their most 
important advocates and agents of the changes, Archbishop Annibale Bugnini (1990). Many of these 20th-century liturgical movements that led to Paul VI's Novus Ordo Mass had roots in the Jansenist liturgical agenda of the 18th century. Before Vatican II there were clear signs of movements that would create a rupture in the ritual habits that had given Roman Catholicism continuity and coherence. The second feature was a view of papal authority that became widespread with Pope Pius IX, which held that the pope had the authority in a fundamental fashion to alter and set aside liturgical tradition. As a result of this view of papal authority, the majority of Roman Catholics accepted the radical liturgical changes instituted by Pope Paul VI. This would have been impossible prior to the further accretion of papal authority subsequent to the Council of Trent (1545-1563), Pius IX (1792-1878, elected 1846), and Vatican I (1869-1870), before which the pope's authority was held to be more limited.

This is not to say that dispute and dissent did not accompany the changes introduced during and after Vatican II. There was a significant minority of Roman Catholics that to various degrees did not agree with the changes and at times reacted in fear regarding their likely consequences. These individuals tended still to have a commitment to the traditional Roman Catholic approaches to medical ethics. They realized that a major disorienting transformation of Roman Catholicism had been initiated. Archbishop Annibale Bugnini himself admits:

The path of liturgical reform has been marked not only by experimentation and adaptation but also by opposition. While some indulged in uncontrolled experimentation, to the detriment of the faith and the sacredness of worship of the Lord, others took a hard stand on the past and launched a systematic attack on the reform (Bugnini 1990, p. 277).

In an attempt to limit the negative reaction that was already salient, the preparation of the new calendar for the Novus Ordo Mass proceeded in secrecy (Bugnini 1990, p. 315). A gulf opened between the reformers and the defenders of the old Mass. The controversies that resulted were strident and were associated with significant demographic changes.

The hemorrhage of clerics and congregants that had begun during Vatican II provoked a warning on September 25, 1969, from Alfredo Cardinal Ottaviani and Antonio Cardinal Bacci (Ottaviani \& Bacci n.d.), that the changes were undermining Roman Catholicism. The difficulties accelerated after the de jure establishment among Roman Catholics of the Novus Ordo Mass in November 1969. Roman Catholicism was marked by a dramatic loss of priests, religious brothers and sisters, and laity. There was in particular a loss of vocations. In the United States, the number of diocesan seminarians fell from 6.3 per ten thousand Roman Catholics in 1965 to 0.51 per ten thousand in 2002 (Jones 2003, p. 29), while the number of religious seminarians fell from 4.87 per ten thousand in 1965 to 0.21 per ten thousand in 2002 (Jones 2003, p. 30). In the seven years following the replacement of the Tridentine Mass by the Novus Ordo Mass in 1970, the number of priests in the world declined from about 410,000 to about 245,000 . The period was also characterized by a major loss of communicants. For example, in the period from 1965 to 1974, weekly church attendance among Canadian Protestants dropped 19\%, but among Canadian Catholics 29\% (Index 1980). As has been observed, "...the ritual chaos within Roman Catholicism surely made a contribution to destabilizing a major social institution in Western culture" (Solomon et al. 2012, p. 12). A remarkable implosion of Roman Catholicism had occurred, marked by a one-shot decline in church practice in the sixties and the early seventies (Greeley 1990). The phenomenon was worldwide (Bouyer 1970). As a consequence, there has been a significant closing of churches due to the decline in the number of both parishioners and priests (Weidemann 1989).

The impact was not just demographic but affected the very character of its scholarship. Roman Catholicism fell into widespread theological chaos. As Richard McCormick observed: The Second Vatican Council, after speaking of the renewal of theological disciplines 
through livelier contact with the mystery of Christ and the history of salvation, remarked simply: 'special attention needs to be given to the development of moral theology." During the past six or seven years moral theology has experienced this special attention so unremittingly, some would say, that the Christianity has been crushed right out of it (McCormick 1981, p. 423).

Roman Catholicism was qualitatively transformed, along with its theological, philosophical, and medical moral assumptions. The style of scholarship had changed through abandoning its Scholastic character, but it was still unclear what kind of theological scholarship should replace it. It was also unclear how it should approach the field of medical ethics. Roman Catholicism had experienced a truly astonishing rupture from its pre-Vatican II past, leading to a recasting of the self-identity of the world's largest Christian denomination. Many Roman Catholics were astonished by the speed, drama, and depth of the changes, not to mention their consequences for the integrity of Roman Catholicism. One might think of a 1971 somewhat polemical volume by John Eppstein, Has the Roman Catholic Church Gone Mad? (Eppstein 1971), which was published with a nihil obstat and an imprimatur, no less.

The result was widespread and foundational liturgical, theological, and bioethical uncertainty, leading to pervasive institutional changes, which often involved a seeming commitment to self-destruction. And so it went. "The less Catholic it is," declared the vice president of Chicago's Mundelein College (which would disappear), "the better the Catholic college will be." A faculty draft report on academic freedom at the University of Dayton, run by the Marianist Fathers, was more blunt. The purpose of a Catholic university, it claimed, was "to become secularized; for to be secularized means to come of age" (Woodward 2013, p. 29).

Within a decade after Vatican II, Roman Catholicism had a substantially different character. The chaos of a Reformation was this time internal to Roman Catholicism and self-inflicted.
In 1971, Newsweek again polled American Catholics for a cover story - "Has the Church Lost Its Soul?" - that, with copious charts, went on for seven pages. What we found was a once apparently cohesive community in disarray: As one liberal monsignor bluntly told us, "The Church is one god-damned mess." Nearly as many American Catholics, for instance, said they now looked for spiritual guidance to evangelist Billy Graham as did those who still looked to the pope. By "soul" I meant "an integral Catholic subculture with its own distinctive blend of rituals and rules, mystery and manners" which, as I saw it then, "has vanished from the American scene" (Woodward 2013, p. 31).

The result was a loss of structure, focus, and mission. Most harmed were orders of nuns.

[T] he Sisters of the Immaculate Heart of Mary splintered into traditional and reformed factions, and the latter eventually disappeared. So did a lot of the other communities of nuns. By the end of the sixties, women's religious orders were reporting defections of up to six thousand a year, plus a precipitous drop in new novices. The vocation crisis, at least in the United States, became a steady state of relentless attrition (Woodward 2013, p. 28).

The widespread and salient presence of Roman Catholicism in healthcare delivery, which once bore the clear stamp of its medical ethics, abruptly went into decline as Roman Catholicism was no longer able to staff its hospitals with religious sisters and brothers. A different Roman Catholicism emerged, and emerged quickly.

The changes after Vatican II, especially after the imposition of the novel Pauline liturgy (i.e., the Novus Ordo mass), were so widespread and disruptive that Pope Paul VI (1963-1978), who had sought them and imposed them, recoiled in horror at what was happening. On the 29th of June, 1972, he mourned, "It was believed that after the Council there would be a day of sunshine in the history of the Church. There came instead a day of clouds, storm and darkness, of search and uncertainty. Through some fissure the smoke of Satan has entered the Temple of God." Vatican II and Pope Paul VI had succeeded in 
letting loose forces that for centuries had been building up in Roman Catholicism (Hull 2010, p. 216-229). Vatican II and the new Pauline mass acted as a catalyst that set off a chain reaction. "'Auto-demolition' was Pope Paul VI's description of the suicidal movement ravaging the Roman Church in the 1970s" (Hull 2010, p. 188). The result was a revolutionary transformation of the life of Roman Catholics that reached from a radically new Mass to the abandonment of old pieties such as fish on Fridays (i.e., abstinence from meat on Fridays). The consequences for bioethics were dramatic, in that these changes in Roman Catholicism also sent into desuetude a 300-year-old literature in medical morality and engendered the circumstances that supported the birth of contemporary bioethics at Georgetown University, a Roman Catholic institution.

\section{From a Scholastic Medical Ethics to Con- temporary Secular Bioethics}

It is only against the background of these wide-ranging ecclesial and theological changes that one can appreciate why the robust medicalmoral literature that existed in Roman Catholicism before and into Vatican II disappeared overnight. This considerable body of medical-moral manuals had taken shape within the manualist tradition that first developed in the early 17 th century, growing out of post-Tridentine Roman Catholicism and the Counter-Reformation. It was a literature to which even Roman Catholic saints such as Alphonsus Maria de Liguori (1696-1787) contributed (Liguori 1862). The manuals were meant to serve as easily accessible resources for Roman Catholic clerics and others, so as uniformly to guide them and to aid them in facing intellectual and moral challenges. These manuals became integral to the intellectual and moral framework of Roman Catholicism. By the end of the 19th century, the manualist project had produced a significant focus on medical-ethical issues, including a large number of medicalmoral manuals in English. It was a significant body of scholarship.

This tradition of medical-moral reflection was characterized by a strong faith in reason. In fact, those who engaged in this enterprise saw themselves not as Roman Catholic or Christian moralists, but as "scientific" moralists simpliciter. They were convinced that they belonged to a moral-scientific tradition that could lay out for all people - atheists, Christians, Jews, and Muslims alike - the norms that should guide the proper conduct of medicine. A striking example of this view is a statement by Fr. Gerald Kelly, S.J., in 1958.

But the [Roman] Catholic moralists do have a just claim to special competence in the science of ethics, the science of moral right and wrong, the science of applying the moral law to the problems of human living. They are highly trained and experienced men in this particular field. Their preparation for this professional capacity is intensive and comprehensive; they usually teach the science of morality over a number of years; and they are constantly dealing with practical applications of this science. Aside from any question of religion, the [Roman] Catholic moralists represent by far the world's largest group of specialists in the science of ethics. And they have a tradition of scientific study that extends over centuries (Kelly 1958, p. 34).

This confidence in reason was mirrored in most examples of this literature. For another instance, consider the claim that Fr. John Kenny, O.P., makes in introducing his book.

Moral principles are not the heritage of any particular religion; they belong to the whole human race, and should be known and practiced by every human being. The application of these principles to the many and varied problems of medical practice constitutes the subject matter of medical ethics. ... It must first be noted that ethics holds to a few postulates which are derived from other fields of philosophy (Kenny 1962, p. 1).

These books in Roman Catholic medicalmoral theology were regarded as works in medical ethics, not in medical-moral theology. Because of its commitment to the univocity of moral rationality, the medical ethics of preVatican II Roman Catholicism saw itself to be the same as proper secular medical ethics. 
In the United States, medical-moral manuals were tied to a parallel tradition of writing codes for physicians and hospitals. These codes developed out of a movement begun in June 1915 (a year after the inception of the Catholic Hospital Association), by Charles B. Moulinier, S.J., which led to Michael P. Bourke overseeing the creation of a code of ethics in 1920 for the Diocese of Detroit. In 1921, a surgical code was adopted by what at the time was styled The Catholic Hospital Association (now called Catholic Health Association). After the Second World War and as progress in medicine accelerated, interest increased in having, as well as giving, direction for the practice of medicine. Out of this background of producing codes of ethics, a document emerged titled "Code of Ethics -1948", first published in 1949. This was followed by one of the most influential of the manuals, the one by Gerald Kelly already quoted above, which functioned as a quasi-companion to the Code. Kelly's book was first published as a series of pamphlets (Kelly 1949, 1950, 1951, 1953, 1954) before its first appearance as a book in 1958 (Kelly 1958).

These and a multitude of other works in this genre were a part of a coherent scholarly tradition recognized within the Roman Catholic academy. It produced a large literature that was approved by the hierarchy and that informed Roman Catholic physicians, healthcare workers, chaplains, and educated laity. It shared a common vision both of the tradition's goals and of its scholarly requirements. It was an established Roman Catholic research program guided by a well-accepted paradigm. The result was that the intellectual footprint of Roman Catholic reflections on medical morality was large. Although this medical ethics tradition was sectarian in depending on a particular sense of the morally rational, those who worked within it were fully unaware of its parochial character. This medicalmoral literature exceeded not only anything produced by Protestants, but even the secular literature of the time.

After Vatican II, the entire project of producing medical-moral manuals collapsed; it abrupt- ly disappeared. As Paul Ramsey succinctly observed, "[t]he day is past when one could write a manual on medical ethics" (Ramsey 1970, p. xvi). With Vatican II, the previous paradigm of Roman Catholic medical ethics was abandoned, along with Roman Catholicism's overarching Scholastic commitments of which it was a part, not because the medical-moral literature had been explicitly rejected, but because the overarching intellectual and moral framework of Roman Catholicism had changed. The Second Vatican Council was supposed to lead to a focus on personalism and biblical study. Although there were publications in bioethics that did style themselves as personalist (Sgreccia 2012), what followed was a crisis of intellectual orientation within which it was unclear as to what scholarly paradigm should guide. Everything had changed. As Paul Ramsey observed, "Due to the uncertainties in Roman Catholic moral theology since Vatican Council II, even the traditional medical ethics courses in schools under Catholic auspices are undergoing vast changes, abandonment, or severe crisis" (Ramsey, 1970, p. xvi).

The abandonment of the centuries-old Scholastic, manualist paradigm was associated with rejection of the old background and overarching paradigms of piety and liturgy in favor of new paradigms of piety and liturgy. Moved by ecumenical concerns, there was an approximation of a reformed Protestant mindset, as Archbishop Bugnini acknowledged: everything was removed from the new liturgy "that could constitute the slightest risk of a stumbling block or a source of displeasure for our Separated Brethren, that is, for the Protestants." There was in addition an attempt made to remove from the Mass "texts that smacked of a negative spirituality inherited from the Middle Ages" (Bugnini 1990, p. 773). The ethos and life-style of Roman Catholicism were transformed. As a consequence, the previous theological and moral paradigm went into crisis, because the more encompassing paradigm for liturgy and piety that determined the mindset of Roman Catholicism had been abandoned. Lex orandi, lex credendi est; the law of prayer is the law of belief. Not only was the Latin Mass 
replaced by a Mass in the vernacular, but the character of the Mass had changed. It was not just that Roman Catholics no longer abstained from meat on Friday or during Lent (with the exceptions of Ash Wednesday and Good Friday), or that Latin was no longer the language of seminaries. The very way of life that had framed Roman Catholicism had changed. Ritual shapes the life-world so that radical changes in ritual lead to radical changes in a way of life (Solomon et al. 2012). With a new approach to its liturgy, prayer, and rules of prayer, a new life-world with a new form of belief was taking shape, although it was unclear what its full character would be. The consequences of Vatican II are still underway. In this new life-world, the old medical ethics tradition was too much a part of the past any longer to seem plausible. However, it was quite unclear as one entered the 1970s what would for Roman Catholicism replace the medical ethics of its manualist tradition.

What followed was a secular bioethics. As John Collins Harvey's (a former member of the International Study Group in Bioethics) account of the development of bioethics has shown, there was a direct connection between post-Vatican II Roman Catholicism and the emergence of secular bioethics (Harvey 2011). As Harvey argues, a crucial role was played by Roman Catholic intellectuals such as André Hellegers (1926-1979), the first director of the Kennedy Institute of Georgetown University, and Sargent Shriver (1915-2011), who through the Kennedy family was its moral and financial backer. They had fully embraced the revolution in piety and liturgy following Vatican II. They were also convinced that a new medical morality was needed and that moral philosophy could elaborate and justify the bioethics and healthcare policy they wanted to embrace. They were sure that this new moral vision could re-direct Roman Catholicism's appreciation of medicine and the biomedical sciences. The result was the creation of the first academic center for the new field: the Center for Bioethics of the Kennedy Institute of Ethics at Georgetown University. The result was a cadre of intellectuals who through publications and through "total immersion" courses engendered, if they did not singlehandedly create, the new field of bioethics.

Hellegers affirmed Vatican II, although he considered himself a liberal dissenter from elements of the magisterium of the post-conciliar church. Being a dissenter, one should note, had become a badge of honor, as is clear from LeRoy Walters' (the first director of the Center for Bioethics within the Kennedy Institute) praise of Hellegers.

In André's own life and work, there are several striking examples of his courage and willingness to protect dissent. The first two Catholic theologians whom André invited to the Kennedy Institute were Warren Reich and Charles Curran. Both had been active in the attempt to reform Catholic moral theology in the late 1960s, and Warren Reich had been a visible and active supporter of Charles Curran when Catholic University and the Vatican had tried to set limits on the scope of his theological inquiries. Warren was the first long-term Catholic scholar at the Institute, and Charles Curran our first visiting scholar. In 1974 and 1975, André invited Bernard Häring, another burr under the Vatican's saddle, to join us as a visiting scholar (Walters 2003, p. 228).

Hellegers was convinced that philosophy and empirical research could and should refashion Roman Catholic medical ethics. For Hellegers, the first point at issue was the Roman Catholic prohibition of artificial contraception, regarding which in particular Hellegers supported change. Hellegers had served on the Roman Catholic Commission considering the acceptability of artificial contraception (McClory 1995). In reaction to Pope Paul VI's condemnation of contraception in Humanae Vitae (1968), Hellegers argued:

Had the encyclical stated that the data, advanced by the commission, were wrong or irrelevant, or were insufficient to warrant a change in teaching, that would have been one thing. It is quite another thing to imply that agreement with past conclusions is the sine qua non for acceptance of a study. Such 
wording pronounced the scientific method of inquiry irrelevant to Roman Catholic theology (Hellegers 1969, p. 217).

Hellegers rejected the theological understanding underlying Humanae Vitae and in its stead proposed a new theological approach. Hellegers had faith in the role that his sense of theological rationality should play in refashioning and developing doctrine.

Hellegers used the Kennedy Institute to bring other dissenters to join in building the nascent field of bioethics. He was confident that this new field of bioethics would support his moral and dogmatic vision. Those who joined Hellegers had the sense that a new and soon-tobe-influential paradigm for medical ethics was emerging. And, of course, they were right. As Warren Reich recalls:

[t] hus, when I came to Georgetown as a "dissenter," I felt radically disconnected from my past academic pursuits and had no clear vision of my professional or intellectual future. Furthermore, after the 1960s I felt that I, together with countless others throughout the world, was experiencing the decisive end of one cultural, moral, and social era and the beginning of another, the contours of which were not yet defined. Thirty-one years later, I see that my serendipitous situation of being suspended between cultures in 1971 was precisely the requisite spiritual and intellectual condition for the task of trying to absorb and articulate the contours, meanings, and normative issues of a new social, intellectual, and political reality that was rapidly taking shape before our very eyes, the future of which we did not know (Reich, 2003, p. 166).

A new paradigm of bioethics took shape and with it a new field of scholarship was established. Within seven years Warren Reich would publish the first edition of The Encyclopedia of Bioethics (1978), aided in part by other persons with theological backgrounds (Warren Reich is a former priest) such as Tom Beauchamp and James F. Childress. There was a hunger for change. Hellegers was able within a Roman
Catholic university to frame a paradigm for a new field, bioethics, which filled the void left by the disappearance of manualist medical ethics. The collapse of the old paradigm, as well as the genesis of the new field of bioethics with its new paradigm of morality and scholarship, can only be appreciated against the background of Vatican II, along with the ecclesial and intellectual crises it engendered, leading to a change in the paradigm for the discipline of medical ethics.

As John Collins Harvey (2013) and Paul Schotsmans (Schotsmans 2005) have shown, the post-Vatican II Roman Catholic influence on the emergence of secular bioethics was exerted not just directly through the Kennedy Institute, but indirectly through Francesc Abel, S.J. Abel was at the Kennedy Institute from the year of its inception (1971) until he returned to Barcelona in 1975 where he played a crucial role in establishing the Institut Borja de Bioethica (Barcelona), as well as the International Study Group in Bioethics of the International Federation of Catholic Universities (one might recall my role beginning in the mid-1980s with the Study Group as mentioned in Chapter One). The result was the genesis out of Roman Catholicism of a secular bioethics movement that came to shape moral reflection on medicine and the biomedical sciences in Western Europe. As Schotsmans summarizes:

Describing bioethics in Europe is impossible without honoring the founding fathers of bioethics. Several eminent bio-ethicists have to be mentioned, like Edouard Bone, S.J. (Brussels, Belgium), Maurice de Wachter (Montreal, Canada, and Maastricht, Netherlands), Richard Nicholson (London, UK), Nicole Lery (Lyon, France), Patrick Vespieren (Paris, France) and-even more than all the others-Francesc Abel (Barcelona, Spain) (Schotsmans 2005, p. 38, quoting Abel 1999, pp. 17-18).

One might note the names of Roman Catholic bioethics scholars such as Bone, de Wachter, and Vesperien. Reviewing the history, Schotsmans concludes that it ...makes clear that bioethics in Europe started mainly in the South 
[i.e., among Roman Catholic thinkers].... The creation of Barcelona's Institut Borja de Bioethica is certainly one of the earliest developments in European bioethics. At the same time, fortunately enough, the European dimension of the bioethical debate was stimulated by the creation of the European Association of Centers of Medical Ethics (EACME). F. Abel played an Institute (with F. Abel) developed an international research and communication network (Schotsmans 2005, p. 38 ff).

Bioethics in Western Europe, like bioethics in the United States, grew out of a change in moral-philosophical focus within Roman Catholicism. The bioethics born of Roman Catholicism was grounded in fully secular moral commitments and premises. The modern secular phenomenon of bioethics, while still drawing on a faith in reason from Roman Catholicism, recast its sense of moral rationality in order to adapt and to fill the scholarly ecological niche in Roman Catholicism that had once been filled by the medical-ethics manualist tradition. The medical ethics of the manualist tradition thought of itself as equivalent to good secular medical ethics, although it carried with it very particular moral understandings rooted in Roman Catholicism (e.g., the natural-law conviction that artificial contraception is forbidden). The new bioethics also carried with it very particular moral premises (e.g., about the capacities of moral philosophy and the existence of human rights), but now after Vatican II and aggiornamento the premises were drawn from the dominant secular culture, not from the history of Roman Catholicism. This bioethics of the 1970s, because it was really a secular bioethics, came to thrive beyond the borders of Roman Catholicism and indeed beyond Christianity. It became the dominant approach to secular bioethics. Now a new crisis threatens in which Roman Catholicism is again playing an important role. Secular bioethics is discovering that the philosophical assumptions it embraced in the 1970s cannot supply a canonical anchor in being or in reason. The bioethics of the 1970s is confronted with post-modernity.

\section{They Never Knew What Hit Them: Aggior- namento Transforms the Cultural Context for Bioethics}

Pope John Paul II, who followed Pope Paul VI after the brief papacy of Pope John Paul I (26 August-28 September 1978), never adequately appreciated the radical character of the postVatican II transformation of Roman Catholicism. Nor did John Paul II rectify the chaos, along with the loss of vocations and congregants that followed Vatican II. If anything, under the papacy of John Paul II the chaos and controversies grew worse because what was taking place, a crisis due to the loss of old paradigms without a full acceptance of a new paradigm, was not adequately understood. The disarray among Roman Catholics proved contagious and affected Protestants as well. As Kenneth Woodward reports, much of what was to happen to Roman Catholicism was already clear at Vatican II and shortly afterwards.

Presbyterian theologian Robert McAfee Brown told me[:] "I concluded that if Catholicism was not going to be the same, then Protestantism is not going to be the same either." ... What struck me most, apart from the headlinemaking results on sex-related issues, was the sheer confusion revealed in the pollsters' personal interviews. The sudden change in traditional dos and don'ts, like abstaining from meat on Fridays, left many Catholics feeling boundaryless. Reading their responses, I remembered what sociologist Peter Berger had said of the curial officials who had warned of chaos if the Council's liberalizing reformers got their way (Woodward 2013, p. 27).

The outcome for mainline Western Christianity has been wide-ranging, involving among other things a demoralization of moral theology, along with a deflation of the force of dogma. People simply lost interest in the Western Christianities.

With Pope John Paul II and Benedict XVI, there were attempts to engage the dominant culture and reach out to those, especially the youth, alienated from a church that had insisted on traditional doctrinal commitments, includ- 
ing a traditional Christian sexual morality that restrained the life-styles of young and old alike. The strategy of outreach that was adopted has not proven successful in restoring numbers of the faithful. As Edward Leigh observes:

It is clear that, over the last 40 years, none of the attempts to woo the young with folk Masses, 'raves in the nave', and so on have [sic] had a significant positive effect on the decline in church-going. Trying to attract converts by making their experience of church-going more like that of their ordinary lives and leisure activities, and by soft-pedalling on 'hard sayings', has clearly failed (Leigh 2009, p. 19).

Another way to put the matter is that the new Pauline liturgy created a new religious space within which traditional morality and dogma did not fit. The loss of congregants and vocations with and after Vatican II was a function of a change of life-world, an abandonment of a paradigm for life that left many Roman Catholics without a bond to the new Roman Catholicism. The rupture had been deep and too abrupt. The post-Vatican II recasting of the life-world of Roman Catholicism did not produce a new Pentecost. The reforms satisfied the personal emotional and intellectual needs of the reformers, but not that of enough of the ordinary congregants, leading to a profound disconnection, which led to a loss of laity and vocations. According to any objective criteria, the post-Vatican II changes were counter-productive. The demographic decline was dramatic. With this collapse of Roman Catholicism, the public space of the West has been redefined. Within this secular public space, as we have seen, secular bioethics has been demoralized and deflated, leading to the question of what this will mean for Roman Catholic and more generally Western Christian bioethics. Will Roman Catholic bioethics also be demoralized and thus set within a "weak" moral theology?

Gianni Vattimo has in particular critically addressed one of the consequences of these developments: the "resecularized religiosity" (Vattimo 2007, p. 94) introduced by John Paul II and continued by Benedict XVI. This "secularized religiosity" has supported the further secular transformation of public spaces, further opening up the cultural niche within which the new secular bioethics flourished. Vattimo addressed these cultural changes in an interview published in 2007 in which he spoke to the discordance between the goals of John Paul II and Benedict $\mathrm{XVI}$ and what was actually produced by their attempts at evangelization.

One of my favorite examples of this comes from the Roman Catholic Church's celebration of the Year of the Jubilee in 2000. Many young people came to Rome to see and hear from the pope. This was perceived by many as an example of the rise in religiosity among today's youth. But, after they had left and when it came time to clean up the area where the youth had spent the night, they found three hundred thousand condoms (Caputo \& Vattimo 2007, p. 96).

Vattimo's interviewer then responded, "The number I heard was actually twenty thousand." Vattimo's riposte was, "No, there were more. Of course, there is difficulty in the counting" (Caputo \& Vattimo 2007, p. 96). Vattimo's point is that the "primitive religiosity" engaged by John Paul II and Benedict XVI (Caputo \& Vattimo 2007, p. 96) through media Masses and youth assemblies has not strengthened, but if anything has further weakened, Roman Catholicism. John Paul II and Benedict XVI's media Catholicism has failed substantively to integrate piety, dogma, and ritual into a new and compelling paradigm. "The threat is that, with the means of the mythologies created by television, we reconstruct a sort of primitive religiosity, a form of superstition - a religious show [is produced] in contrast to devotion" (Caputo \& Vattimo 2007, p. 96).

Vattimo appreciates that in a desperate need to attract back lost flock, a media Catholicism has been produced that is only further severed from the substance of Christianity. That is, there has been an attempt to draw large crowds grounded in a decision the Vatican has taken in order to begin to attract all those people who left the Church because of the dogmatic preaching of Pope John Paul II. And although I still haven't heard about the number of condoms left after 
World Youth Day in Cologne [2005], I did read about a controversy that arose over plans for police to distribute condoms at World Youth Day. The church tried to halt plans to distribute them, according to the spokeswoman of the German police unions (the union commonly distributes them at large public gatherings to protect the public)" (Caputo \& Vattimo 2007, pp. 96-97).

The commitment to reconnect with the youth and others alienated from Western Christianity has occurred without acknowledging the constraints set by traditional moral norms, leading to the bizarre outcomes that Vattimo notes. The attempts of John Paul II and Benedict XVI may have only further abetted secularization and encouraged the enlargement of the cultural space within which a demoralized bioethics can flourish. Once again, Roman Catholicism turns out to be changing the cultural geography so that bioethics will be further refashioned, this time as a bioethics after modernity.

In contrast, traditionalist Christians have for many reasons held their own. In part, this may be because the majority of them, especially fundamentalist Protestants, are not embedded within the moral-philosophical assumptions that tied much of mainline Western Christianity, first and foremost Roman Catholicism, to the conceits of secular moral philosophy and thus to secular culture. Mainline Christians have more consanguinity with the philosophy-oriented, so-called via antiqua. After all, mainline Western Christianity is a close sibling of the contemporary, dominant, secular culture as a result of mainline Christianity's commitment to the prevailing secular morality and moral philosophy. The mainline Christian churches of the West have also supported the secularization of the West through rendering Christian concerns for the transcendent into immanent concerns for a social gospel, and for social justice, that is to be articulable and justifiable without reference to God, much less to Christ. As with Pope Francis I, as will shortly be shown, there was a move from the bioethics of sexuality, reproduction, and end-of-life decision-making to a focus on social justice and the allocation of healthcare resources.
One might recall Friedrich Hayek's observation that when Christian clerics talk of social justice rather than of obligations to charity, it is an indication of an immanent displacement of a once transcendent moral-metaphysical view and its concerns. They have likely lost their faith. [Social justice] seems in particular to have been embraced by a large section of the clergy of all Christian denominations, who, while increasingly losing their faith in a supernatural revelation, appear to have sought a refuge and consolation in a new "social" religion which substitutes a temporal for a celestial promise of justice, and who hope that they can thus continue their striving to do good. The Roman Catholic church especially has made the aim of "social justice" part of its official doctrine; but the ministers of most Christian denominations appear to vie with each other with such offers of more mundane aims - which also seem to provide the chief foundation for renewed ecumenical efforts (Hayek 1976, p. 66).

Talking about social justice allowed the mainline Christian churches to disengage from traditional belief and yet still seem to be Christian. One should recall that Christianity in the first three centuries did not preach social justice to the Roman Empire, but instead charity. The Church of the first centuries did not trust that a pagan government would rightly tend to the needs of the poor. To the contrary, Christians were sure that the empire's social justice would be a pagan social justice hostile to Christian commitments. Second, and more importantly, the obligation to feed the poor fell on Christians themselves who are required personally to turn to the poor in need. Social justice is not a concept with roots in the Apostles and the Fathers. There is instead in Christianity a radical demand to turn personally to meet the needs of the poor. In contrast, post-traditional Christianity has socialized charity and in the process reshaped the cultural context, along with bioethics and healthcare policy, within which law and public policy are appreciated by the Western Christianities (Francis I 2013). 


\section{REFERENCES}

Abbate, Carmelo. 2011. Sex and the Vatican. Milan: Piemme.

Abel, Francesc. 1999. Bioethical dialogue in the perspective of the third millennium. Unpublished paper delivered in Barcelona, May 9.

Anonymous. 2014. Pope Francis: put-down artist? New Oxford Review LXXXI.3 (April): 17-20.

Anonymous. 2013a. Pope Francis, Foreign Policy (December): 86.

Anonymous. 2013b. Pope Francis and the primacy of conscience, New Oxford Review 80 (December): 18-21.

Anonymous. 2013c. Pope Francis: Delight of the world, New Oxford Review 80 (December): 21-23.

Aquinas, Thomas. 1947. Summa Theologiae, 2nd Part of the 2nd Part, Question 154, Article 12, trans. Fathers of the English Dominican Province. New York: Benziger Brothers.

Archdiocese Saltzburg. 2009. Bei Gott und den Menschen bleiben! Ein Interview mit Erzbischof Alois Kothgasser zur Lage der Kirche (February 10). Available: http://www.kirchen.net/portal/page.asp?id=13622 [accessed October 7, 2013]

Badash, David. 2011. "Sex and the Vatican" claims thousands of priests in illicit relationships. http://thenewcivilrightsmovement.com/sex-and-the-vatican-claims-thousands-of-priests-in-illicit-relationships/news/2011/04/20/19057 [Accessed February 23, 2013]

Basil, St. 1994. Basil: Letters and Select Works, in Nicene and Post-Nicene Fathers, Second Series, eds. Philip Schaff and Henry Wace, vol. 8. Peabody, MA: Hendrickson Publishers.

Benedict XVI. 2013. Benedict XVI leaves the papacy, L'Osservatore Romano 46.7 (February 13): 1.

Benedict XVI. 2007. Summorum pontificium, 7 July.

Biblia Sacra. 1956. Rome: Typis societatis S. Joannis Evang.

Bottum, Joseph. 2008. The death of Protestant America: A political theory of the Protestant mainline, First Things 186 (Aug/ Sept): 23-33.

Bouyer, Louis. 1970. Der Verfall des Katholizismus. Munich: Kösel.

Bradshaw, David. 2004. Aristotle East and West. New York: Cambridge University Press.

Brzana, Stanislao J. 1953. Remains of Sin and Extreme Unction According to Theologians after Trent. Rome: Catholic Book Agency.

Buckley, Michael. 1987. At the Origins of Modern Atheism. New Haven: Yale University Press.

Bugnini, Annibale. 1990. The Reform of the Liturgy 1948-1975, trans. Matthew J. O'Connell. Collegeville, MN: Liturgical Press.

Bugnini, Annibale. 1965. Le "variationes" al alcuni testi della Settimana Santa, L'Osservatore Romano 65 (March 19): 6. Cadge, Wendy, Laura R. Olson, \& Christopher Wildeman. 2008. How denominational resources influence debate about homosexuality in mainline Protestant congregations, Sociology of Religion 69.2:187-207.

Cahill, Lisa Sowle. 2005. Theological Bioethics: Participation, Justice, and Change. Washington, DC: Georgetown University Press.

Camosy, Charles. 2012. Peter Singer and Christian Ethics. New York: Cambridge University Press.

Caputo, John D. \& Gianni Vattimo. 2007. After the Death of God, ed. Jeffrey W. Robbins. New York: Columbia University Press. Chrysostom, St. John. 1994. Homily XII on Colossians iv.12,13. In: Philip Schaff (ed.), Nicene and Post-Nicene Fathers, First Series. Peabody, MA: Hendrickson Publishers.

Chua-Eoan, Howard \& Elizabeth Dias. 2013. The people's pope, Time 182.26: 46-75.

Clegg, Sally \& Cathy Pharaoh. 2006. International comparisons of charitable giving: November 2006. www.cafonline.org/ pdf/International Comparisons of Charitable Giving.pdf [accessed December 20, 2013]

Collins, Anthony. 1713. A Discourse of Free-thinking. London.

Curran, Charles E. 1976. Catholic Moral Theology in Dialogue. Notre Dame, IN: University of Notre Dame Press.

D'Antonio, Michael. 2013. More catholic than the pope? Foreign Policy (July 30). http://www.foreignpolicy.com/articles/2013/07/30/more_catholic_than_the_pope-Francis_homosexuality_reform [accessed October 2, 2013]

Denzinger, Henricus. 1965. Enchiridion Symbolorum, 33rd ed. Freiburg im Breisgau: Herder.

Didache, The. 1965. Trans. Kirsopp Lake, in Apostolic Fathers, 2 vols. (vol. 1, pp. 303-333). Cambridge, MA: Harvard University Press.

Dionne, E. J., Jr. 2013. Resurrection, Foreign Policy (December): 88-89.

Dobszay, László. 2010. The Restoration and Organic Development of the Roman Rite, ed. Laurence Paul Hemming. New York: T \& T Clark.

Donadio, R. 2013. On gay priests, Pope Francis asks, 'Who am I to judge?' New York Times (July 30): A1.

Dorrien, Gary. 2013. America's mainline, First Things 237 (November): 27-34.

Durkheim, Émile. 1947. The Elementary Forms of the Religious Life, trans. Joseph Swain. Glencoe, IL: Free Press; 1st ed., 1915.

Ellard, Gerald. 1948. The Mass of the Future. Milwaukee: Bruce Publishing.

Engel, Randy. 2006. The Rite of Sodomy. Export, PA: New Engel Publishing.

Engel, Ulrich. 2001. Religion and violence: Plea for a weak theology in tempore belli, New Blackfriars 82: 558-560. 
Engelhardt, H. T., Jr. 2012. Ritual, virtue, and human flourishing: Rites as bearers of meaning. In: Ritual and the Moral Life: Reclaiming the Tradition (pp. 29-51), eds. David Solomon, Ping-Cheung Lo, Ruiping Fan. Dordrecht: Springer.

Engelhardt, H. T., Jr. 2011. Orthodox Christian bioethics: Some foundational differences from Western Christian bioethics, Studies in Christian Ethics 24.4 (November): 487-499.

Engelhardt, H. T., Jr. 2010a. Political authority in the face of moral pluralism: Further reflections on the non-fundamentalist state, Notizie di Politeia 26.97: 91-99.

Engelhardt, H. T., Jr. 2010b. Religion, bioethics, and the secular state: Beyond religious and secular fundamentalism, Notizie di Politeia 26.97: 59-79.

Engelhardt, H. T., Jr. 2000. The Foundations of Christian Bioethics. Salem, MA: Scrivener Publishing.

Eppstein, John. 1971. Has the Catholic Church Gone Mad? New Rochelle, NY: Arlington House.

Evagrios the Solitary. 1983. On prayer. In: St. Nikodimos and St. Makarios, The Philokalia, trans. and eds. G. E. H. Palmer, Philip Sherrard, \& Kallistos Ware (pp. 55-71). Boston: Faber and Faber.

Fackenheim, Emil. 1967. The Religious Dimension in Hegel's Thought. Bloomington: Indiana University Press.

Fidora, Alexander. 2013. Dominicus Gundissalinus and the introduction of metaphysics into the Latin west, Review of Metaphysics 67.4 (June): 691-712.

Francis I, pope. 2013. Evangelii Gaudium. Vatican City: Vatican Press.

Friess, Horace L. 1981. Felix Adler and Ethical Culture. New York: Columbia University Press.

Fuchs, Joseph. 1980. Is there a specifically Christian morality? In Readings in Moral Theology No. 2: The Distinctiveness of Christian Ethics (pp. 3-17), eds. Charles Curran and Richard McCormick. New York: Paulist Press.

Gilbert, Alan D. 1980. The Making of Post-Christian Britain. London: Longman.

Greeley, Andrew M. 1990. The Catholic Myth. New York: Scribner's Sons.

Griese, Orville N. 1987. Catholic Identity in Health Care: Principles and Practice. Braintree, MA: Pope John Center.

Hapgood, Isabel (ed. and trans.). 1996. Service Book of the Holy Orthodox-Catholic Apostolic Church, 7th ed. Englewood, NJ: Antiochian Orthodox Christian Archdiocese.

Harvey, John Collins. André Hellegers, the Kennedy Institute, and the development of bioethics: The American-European Connection, in: The Development of Bioethics in the United States, eds. Jeremy Garrett, Fabrice Jotterand, \& D. Christopher Ralston (pp. 37-54). Dordrecht: Springer.

Hauerwas, Stanley. 1995. How Christian ethics became medical ethics: The case of Paul Ramsey, Christian Bioethics 1(1): $11-28$.

Hauerwas, Stanley. 1979. Theological reflections on in vitro fertilization, in: HEW Support of Research Involving Human In Vitro Fertilization and Embryo Transfer (pp. 1-20). Washington, DC: U. S. Government Printing Office.

Hayek, Friedrich. 1976. The Mirage of Social Justice. Chicago: University of Chicago Press.

Hayford, Saraah R. and S. Philip Morgan. 2008. Religiosity and fertility in the United States: The role of fertility intentions, Social Forces 86.3: 1163-1188.

Hellegers, André. 1969. A scientist's analysis, in: Contraception: Authority and Dissent, ed. C. E. Curran (pp. 216-239). New York: Herder and Herder.

Hess, Jonathan M. 2002. Germans, Jews and the Claims of Modernity. New Haven, CN: Yale University Press.

Hilarion [Alfeyev]. 2008. Theological education in the 21st century, lecture given at Wycliffe College, University of Toronto, October 22. Available at: http://www.interfax-religion.com/?act=documents\&div=134 [accessed September 30, 2013].

Hinch, Jim. 2013. Where are the people? The American Scholar (Winter). http://theamericanscholar.org/where-are-thepeople/\#.UrMOLSfw2ko (Accessed December 20, 2013).

Holy Apostles Convent. 2000. Acts, Epistles, and Revelation. Buena Vista, CO: Holy Apostles Convent.

Hout, Michael, Andrew Greeley, \& Melissa J. Wilde. 2001. The demographic imperative in religious change in the United States, American Journal of Sociology 107.2: 468-500.

Hull, Geoffrey. 2010. The Banished Heart: Origins of Heteropraxis in the Catholic Church. London: T\&T Clark.

Hunter, James Davison. 1991. Culture Wars. New York: Basic Books.

Hutchison, William R. 1989. Between the Times: The Travail of the Protestant Establishment in America, 1900-1960. New York: Cambridge University Press.

Index to International Public Opinion, 1978-1979. 1980. Westport, CN: Greenwood Press.

ITV Staff. 2013. The interview that shook the world, Inside the Vatican 21.9 (November): 17-21.

John Paul II. 1998. Fides et ratio. Vatican City: Libreria editrice vaticana.

John Paul II. 1993. Veritatis splendor. Vatican City: Libreria editrice vaticana.

Jones, Kenneth C. 2003. Index of Leading Catholic Indicators: The Church since Vatican II. Fort Collins, CO: Roman Catholic Books.

Jungmann, Joseph A. 1951. The Mass of the Roman Rite: Its Origins and Development, trans. Francis A. Brunner. New York: Benziger Brothers.

Kant, Immanuel. 1960. Religion within the Limits of Reason Alone, trans. Theodore Greene \& Hoyt Hudson. New York: Harper Torchbooks. 
Katz, Jacob. 1993. Tradition and Crisis: Jewish Society at the End of the Middle Ages, trans. Bernard Cooperman. New York: Schocken Books.

Kelly, David F. 1979. The Emergence of Roman Catholic Medical Ethics in North America. New York: Edwin Mellen Press. Kelly, Gerald. 1949. Medico-moral problems, Part I. St. Louis, MO: Catholic Hospital Association.

Kelly, Gerald. 1950. Medico-moral problems, Part II. St. Louis, MO: Catholic Hospital Association.

Kelly, Gerald. 1951. Medico-moral problems, Part III. St. Louis, MO: Catholic Hospital Association.

Kelly, Gerald. 1953. Medico-moral problems, Part IV. St. Louis, MO: Catholic Hospital Association.

Kelly, Gerald. 1954. Medico-moral problems, Part V. St. Louis, MO: Catholic Hospital Association.

Kelly, Gerald. 1958. Medico-Moral Problems. St. Louis, MO: Catholic Hospital Association.

Kenny, John P. 1962. Principles of Medical Ethics, 2nd ed. Westminster, MD: Newman Press.

Kidd, Thomas. 2013. Papal homecoming, World 28.17 (August 24): 64.

Kraut, Benny. 1979. From Reform Judaism to Ethical Culture: The Religious Evolution of Felix Adler. Cincinnati: Hebrew Union College Press.

Leigh, Edward. 2009. Grave symptoms, in The Nation that Forgot God, eds. Edward Leigh \& Alex Haydon (pp. 11-21). London: Social Affairs Unit.

Liguori, Alphonsus de. 1862. Theologia moralis, ed. Michael Heilig. 6 vols. Paris: Adrianus le Clere.

Liturgikon, The. 1994. Englewood, NJ: Antakya Press.

Longman, Phillip. 2006. The return of patriarchy, Foreign Policy 153 (March/April): 56-65.

Longman, Phillip. 2004a. The Empty Cradle. New York: Basic Books.

Longman, Phillip. 2004b. The global baby bust, Foreign Affairs 83.3 (May/June): 64-79.

Luckmann, Thomas. 1990. Shrinking transcendence, expanding religion? Sociological Analysis 51.2: 127-138.

Madambashi, Andrea. 2011. Half of Brazil's population to be evangelical by 2020, Christian Post U.S. [On-line] http://www. christianpost.com/news/half-of-brazils-population-to-be-evangelical-christian-by-2020-49071/ [accessed February 3, 2014] Maimonides, Moses. 2001. Mishneh Torah. New York: Moznaim Publishing.

Martini, Cardinal Carlo, \& Georg Sporschill. 2012. Night Conversations with Cardinal Martini, trans. Lorna Henry. New York: Paulist Press.

McClory, Robert. 1995. Turning Point: The Inside Story of the Papal Birth Control Commission. New York: Crossroads.

McCormick, Richard. 1981. Notes on moral theology, 1965 through 1980. Washington, DC: University Press of America. Merleau-Ponty, M. 1969. Humanism and Terror, trans. John O'Neill. Boston: Beacon Press.

Meyer, Michael (ed.). 1997. German-Jewish History in Modern Times, vol. 2, Emancipation and Acculturation $1780-1871$. New York: Columbia University Press.

Miller, Terry. 2014. America's dwindling economic freedom, Wall Street Journal 263.11 (January 14): A13.

Mitchell, Peter. 1980. The Jesuits: A History. London: Macdonald.

Monk of St. Tikhon's Monastery. 1987. Book of Needs. South Canaan, PA: St. Tikhon's Seminary Press.

Motzkin, Gabriel. 1992. Time and Transcendence: Secular History, the Catholic Reaction, and the Rediscovery of the Future. Dordrecht: Kluwer.

Moynihan, Daniel Patrick. 1965. The Negro Family: A Case for National Action. Washington, DC: U.S. Department of Labor. Nadeau, Barbie. 2013. Did a cross-dressing priest sex ring bring down Benedict XVI? The Daily Beast (February 22). http:// news.yahoo.com/did-cross-dressing-priest-sex-ring-bring-down-174300640--politics.html [Accessed February 22, 2013]

Nemeth, Roger J. \& Donald A. Luidens. 1989. The new Christian right and mainline Protestantism: The case of the Reformed Church in America, Sociological Analysis 49.4: 343-352.

Nicodemus and Agapius, Sts. (eds.). 1983. The Rudder of the Orthodox Catholic Church, trans. D. Cummings. Chicago: Orthodox Christian Educational Society.

Noè, Cardinal Virgilio. 2008. CWNEws.com, 16 May 2008; www.catholicculture.org/news/features/index.cfm?recnum=58473 [accessed 23 Sept. 2013]

Novak, Michael. 2013. Agreeing with Pope Francis, National Review Online; http://www.nationalreview.com/node/365720/ [accessed January 25, 2014]

Ottaviani, Alfredo \& Antonio Bacci. N.d. Breve esame critica del "Novus Ordo Missae". Rome: Fondazione "Lumen gentium". Overbeck, Franz. 1919. Christentum und Kultur. Basel: Schwabe.

Pera, Marcello. 2011. Why We Should Call Ourselves Christians: The Religious Roots of Free Societies, trans. L. B. Lappin. Jackson, TN: Encounter.

Perniola, Mario. 2001. Ritual Thinking, trans. Massimo Verdicchio. Amherst, NY: Humanity Books.

Perry, John. 2013. Utility of utility, First Things 231: 17.

Petrà, Basilio. 2011. I limiti dell'innocenza. Bologna: Edizioni Dehoniane Bologna.

Pocket Prayer Book for Orthodox Christians. 1956. Englewood, NJ: Antiochian Orthodox Christian Archdiocese.

Ramsey, Paul. 1970. The Patient as Person. New Haven, CT: Yale University Press.

Ratzinger, Joseph, \& Marcello Pera. 2006. Without Roots, trans. Michael F. Moore. New York: Basic Books. 
Reed, John Chelton. 1970. The Glorious Battle: The Cultural Politics of Victorian Anglo-Catholicism. Nashville: Vanderbilt University Press.

Reich, Warren. 2003. Shaping and mirroring the field: the Encyclopedia of Bioethics in: The Story of Bioethics, eds. J. Walter \& E. Klein (pp. 165-196). Washington, DC: Georgetown University Press.

Reno, R. R. 2014. Francis and the market, First Things 240 (February): 3-5.

Roberts, Jason A. 2011. Reasons for Resistance: The Hierarchy of the Catholic Church Speaks on the Post-Vatican II Crisis. Raleigh, NC: Queen of Martyrs Press.

Robbins, Jeffrey W. 2004. Weak theology, Journal of Cultural and Religious Theory 5.2: 1-4.

Romanides, John S. 2008. Patristic Theology, trans. Hieromonk Alexios (Trader). Dalles, OR: Uncut Mountain Press.

Romanides, John S. 2002. The Ancestral Sin, trans. George S. Gabriel. Ridgewood, NJ: Zephyr Publishing.

Rorty, Richard. 2004. Foreword, in Gianni Vattimo, Nihilism \& Emancipation, ed. Santiago Zabala, trans. William McCuaig (pp. ix-xxiii). New York: Columbia University Press.

Rorty, Richard. 1991. Objectivity, Relativism, and Truth. New York: Cambridge University Press.

Rose, Michael S. 2014. The associate editor replies, New Oxford Review 81.1 (Jan.-Feb.): 13-14.

Runciman, Stephen. 1955. The Eastern Schism. Oxford: Oxford University Press.

Scalfari, Eugenio. 2013a. The pope: how the church will change, La Repubblica (October 1) http://www.repubblica.it/ cultura/2013/10/01/news/pope_s_conversation_with_scalfari_english-67643118/ [accessed April 12, 2014], trans. Kathryn Wallace.

Scalfari, Eugenio. 2013b. http://www.vatican.va/holy_father/francesco/speeches/2013/october/documents/papa-francesCO_20131002_intervista-scalfari_en.html [accessed April 12, 2014]

Schaff, Philip \& Henry Wace. 1994. Seven Ecumenical Councils, vol. 14 of Nicene and Post-Nicene Fathers. Peabody, MA: Hendrickson Publishers.

Schotsmans, Paul. 2005. Integration of bio-ethical principles and requirements into European Union statutes, regulations and policies, Acta Bioethica 11:37-46.

Schott, Anselm. 1961. Das vollständige Römische Messbuch. Freiburg im Breisgau: Herder.

Sgreccia, Elio Cardinal. 2012. Personalist Bioethics: Foundations and Applications, trans. John di Camillo \& Michael Miller. Philadelphia: National Catholic Bioethics Center.

Shapiro, Edward S. 2014. The decline and rise of secular Judaism, First Things 241 (March): 41-46.

Shuster, Simon. 2013. The world according to Putin, Time 182.12 (September 16): 30-35.

Singer, Peter. 2011. Practical Ethics, 3rd ed. New York: Cambridge University Press.

Solomon, David, Ping-Cheung Lo, Ruiping Fan, \& H. Tristram Engelhardt, Jr. 2012. Ritual as a cardinal category of moral reality: An introduction, in Ritual and the Moral Life, eds. David Solomon, Ping-Cheung Lo, \& Ruiping Fan (pp. 1-13). Dordrecht: Springer.

Sopko, Andrew J. 1998. The Theology of John Romanides. Dewdney, B.C., Canada: Synaxis Press.

Tanner, Norman P. (ed.). 1990. Decrees of the Ecumenical Councils, 2 vols. Washington, DC: Georgetown University Press. Taylor, Charles. 1975. Hegel. Cambridge: Cambridge University Press.

Trilling, Lionel. 1966. Beyond Culture. London: Secker \& Warburg.

Vasileios [Gontikakis]. 1984. Hymn of Entry, trans. Elizabeth Briere. Crestwood, NY: St. Vladimir's Seminary Press.

Vattimo, Gianni. 2005. What is religion's future after metaphysics? in Richard Rorty and Gianni Vattimo, The Future of Religion, ed. Santiago Zabala (pp. 55-81). New York: Columbia University Press.

Vattimo, Gianni. 2002. After Christianity, trans. Luca D'Isanto. New York: Columbia University Press.

Vattimo, Gianni. 1982. Ornamento monumento, Rivista di estetica 12: 36-43.

Vattimo, Gianni \& René Girard. 2010. Christianity, Truth, and Weakening Faith, ed. Pierpaolo Antonello, trans. William McCuaig. New York: Columbia University Press.

Vattimo, Gianni \& Pier Rovatti (eds.). 1983. Il pensiero dobele. Milan: Feltrinelli.

von Hartmann, Eduard. 1874. Die Selbstzersetzung des Christenthums. Berlin: Duncker's.

Walters, L. (2003). The birth and youth of the Kennedy Institute of Ethics, in The Story of Bioethics, eds. J. Walter \& E. Klein (pp. 215-231). Washington, DC: Georgetown University Press.

Weidemann, Siggi. 1989. Altäre unter dem Hammer, Süddeutsche Zeitung, April 18.

Wicks, Peter. 2013a. Utility's deceptions, First Things 229 (January): 59-61.

Wicks, Peter. 2013b. Peter Wicks replies, First Things 231 (March): 17.

Woodward, Kenneth L. 2013. Reflections on the revolution in Rome, First Things 230 (February): 25-31.

Zabala, Santiago. 2005. A religion without theists or atheists, in Richard Rorty and Gianni Vattimo, The Future of Religion, ed. Santiago Zabala (pp. 1-27). New York: Columbia University Press. 